\title{
Ensaio sobre a Cegueira: ética, sociedade e filosofia
}

Geraldo José Hillesheim ${ }^{32}$

Antes de abordar as nuances filosóficas encontradas no filme Ensaio Sobre a Cegueira (2008), de direção de Fernando Meirelles, afim de chegar a uma conclusão sobre o imbricamento entre filosofia e cinema, é necessário fazer algumas considerações.

Primeiramente, não é o filósofo que constrói a peça cinematográfica, mas o cineasta que se utiliza da linguagem filosófica para definir o enredo. Talvez, por isso, Cabrera (2006) faz a distinção entre filósofos páticos e apáticos, pois existem ideias mais passíveis de serem utilizadas em roteiros que outras, notadamente, aquelas que buscam a emoção à racionalidade pura. Entretanto, diante dessa alegação, um primeiro problema é apresentado: a filosofia não perscruta as emoções no sentido da existencialidade, cabendo à psicanálise contextualizar tais fatos. Assim, seria o cinema filosófico ou psicanalítico?

Outro aspecto importante a ser levantado é o etnográfico, ou seja, são sobrepostas várias camadas culturais entre a ideia filosófica crua e a apresentação do filme pronto. Quer dizer, o roteirista se debruça sobre um tema ou ideia que deseja escrever, depois o roteiro é apresentado ao produtor, passando por um diretor, que propõe uma releitura do texto. Em seguida, o texto chega aos atores que, conduzidos pelo diretor, interpretam-no emocionalmente, até que, finalmente, chega a uma pequena minoria de críticos profissionais, financiados por editores para analisar o filme em questão. Por fim, com a influência dos críticos, que são os formadores de opinião, o filme chega ao grande público. O ponto fulcral filosófico, da ideia inicial, foi aquele que chegou até o grande público?

Além disso, para definir o cinema como filosófico, é necessário fazer uma análise do problema linguístico. A filosofia sempre se utilizou da literatura para se demonstrar, ou seja, a linguagem padrão do filósofo sempre foi a escrita. Em contrapartida, o cinema se utiliza de conceitos-imagens para se definir e apresentar seu

\footnotetext{
${ }^{32}$ Graduado em Filosofia pelo Claretiano Centro Universitário. E-mail: gj.hilles@ gmail.com
} 
discurso.

Apesar de o cinema ter seus roteiros partindo da escrita e da literatura, é possível observar dois discursos distintos: um literário e outro pictórico. Os conceitos-imagens buscam estabelecer uma experiência impactante na audiência, da mesma forma que Bertold Brecht teoriza no teatro a proposição da catarse por meio do drama apresentado. Contudo, a filosofia propõe um saber reflexivo, ao invés de uma pulsão catártica.

Por conseguinte, esta análise linguística aponta para uma incompatibilidade, que, de certa forma, levaria ao questionamento se realmente há um discurso cinematográfico-filosófico, por mais que exista uma aproximação dos temas filosóficos com os enredos.

Ainda, ao debruçar-se sobre a produção cinematográfica dos últimos cem anos, é possível observar que, da mesma forma que a cultura do super-homem foi idealizada pelas produções hollywoodianas, muitos filmes tiveram como tema o homem comum, como é evidente no cinema europeu. O problema é que ambos possuem clichês estéticos já bem formados, e muitas vezes repetidos. Se, por um lado tem-se a nação que lidera e salva o mundo no papel do herói, do outro tem-se o homem angustiado perante o mundo. Adorno, já no livro Dialético do Esclarecimento, constrói suas ideias sobre a indústria cultural e contesta o cinema enquanto arte além, de caracterizá-lo como o carro-chefe do establishment.

Por isto, de uma maneira geral, devido às camadas culturais, ao problema da linguística, e ao viés de entretenimento de massa, fica difícil fazer uma relação mais estreita entre filosofia e cinema. Neste caso, a filosofia se desdobra no cinema, mas não é o cinema.

Contudo em alguns casos particulares, certas películas como o filme Ensaio sobre a Cegueira (2008), dirigido por Fernando Meirelles, podem ter uma feição artístico-filosófica. Estes são definidos a partir de uma conceituação mais profunda, um enquadramento mais crítico, e uma leitura mais fiel às ideias do autor, levando o expectador a uma reflexão interpretativa sobre a obra.

Do ponto de vista filosófico, o filme Ensaio sobre a Cegueira tem múltiplas interpretações, sendo possível fazer diversas leituras sobre a obra, o que justifica seu grau de complexidade elevado. Uma das possíveis interpretações que podem corroborar o entrelinhamento filosófico do filme são as ideias da modernidade líquida de Bauman (2001). 
Saramago, quando escreve o livro, procura mostrar a perda da razão do indivíduo social diante dos aspectos da pós-modernidade. $\mathrm{O}$ autor se vale da epidemia de cegueira para abordar esta ideia. Da mesma forma, Bauman (2001) percebe o mundo de forma líquida, fluída, incapaz de manter uma concretude, quando se deseja construir valores. $\mathrm{O}$ escritor português e o filósofo polonês chegam à mesma conclusão refletindo sobre a sociedade: uma individualização exacerbada, onde há conflitos internos sem uma aparente solução; o indivíduo enquanto mercadoria e uma sociedade em constante transformação. Por isto é possível observar na obra de Saamago nuances das ideias filosóficas de Bauman (2001).

No filme, o surto é uma cegueira branca, sendo possível interpretar como um ruído branco, ou seja, o sujeito enxerga tudo e não foca em nada, como se enxergasse tanto que se deixa de ver. As análises são superficiais e não há aprofundamento nas idéias. Tudo é descartável e, nas relações com o coletivo, o indivíduo não enxerga o outro. A epidemia apresentada, por analogia, pode ser definida como uma epidemia de cegueira moral. A sobrevivência individual é o que mais importa para os cegos. Dentro do caos instituído pela cegueira, o indivíduo se revela insensível diante dos problemas alheios, sendo incapaz de percebê-los. A conduta do indivíduo fica cada vez mais egoísta, vivendo uma ética de resultados. A intersubjetividade do aspecto ético não é levada em consideração.

Saramago (2001) não coloca nome em seus personagens, demonstrando um sujeito que deixou de ter identidade é tornou-se uma massa disforme, pronta para ser mais uma das engrenagens do consumismo. O sujeito se volta para dentro de si, não de forma a refletir, mas de maneira a se tornar um "autista consciencial". Com isto, os valores se perdem, a solidariedade deixa de existir e os códigos de conduta são alterados, justificando a massificação do social.

Apesar de tudo, o indivíduo social ainda tem uma chance de se recuperar da cegueira moral que o acossa, ao perceber e interpretar o mundo de forma coletiva, desprendendo-se da ética dos resultados e focando na ética dos princípios. Desta forma, permite-se uma mudança radical na forma de perceber os valores, passando da instabilidade fluídica para a, notadamente, essencial e permanente. 
Revista do NESEF Filosofia e Ensino. Educação Filosófica no contexto das políticas púbicas educacionais

\section{Referências}

BAUMAN, Z. Modernidade líquida. Rio de Janeiro: Jorge Zahar, 2001.

CABRERA, J. O Cinema Pensa. Rio de Janeiro: Rocco, 2006.

SARAMAGO, J.Ensaio sobre a cegueira. 19a. ed. São Paulo: Cia. das Letras, 2001. 